\title{
TRANSFORMASI MODEL BISNIS GO-JEK UNTUK KEUNGGULAN-KOMPETITIF DALAM PERKEMBANGAN EKONOMI-BERBAGI DARI SUDUT PANDANG PELANGGAN
}

\author{
Berta Salim \\ Magister Manajemen, Universitas Bunda Mulia \\ Alamat surel: berta.salim@yahoo.com \\ John J.O.I. Ihalauw \\ Magister Manajemen, Universitas Bunda Mulia \\ Alamat surel: ihalauw@bundamulia.ac.id
}

\begin{abstract}
Currently Go-Jek is an application for many services. This study aims to know the effect of Go-Jek's business model transformation to preserve the company's competitive advantage in the economy-sharing development from the customer's point of view. The results show that the transformation of Go-Jek's business model from just an online motorcycle taxi into an application with many services changed the Go-Jek business concept, the added value felt by customers and this effectively preserved Go-Jek's competitive advantage and strengthened Go-Jek's position in an sharing-economy market.
\end{abstract}

Keywords: business model, competitive advantage, sharing-economy.

\begin{abstract}
Abstrak
Saat ini Go-jek adalah aplikasi untuk banyak layanan. Penelitian ini bertujuan untuk mengetahui pengaruh transformasi model bisnis Go-jek untuk melestarikan keunggulan-kompetitif perusahaan dalam perkembangan ekonomi-berbagi dari sudut pandang pelanggan. Hasil penelitian menunjukkan bahwa transformasi model bisnis Go-jek dari hanya ojek daring menjadi aplikasi dengan banyak layanan mengubah konsep bisnis Go-jek, yang nilai tambah yang dirasakan oleh pelanggan dan hal ini efektif melestarikan keunggulan-kompetitif Go-jek dan memperkuat posisi Go-jek dalam perkembangan ekonomi-berbagi.
\end{abstract}

Kata Kunci: model bisnis, keunggulan kompetitif, ekonomi-berbagi

\section{PENDAHULUAN}

Go-Jek adalah sebuah perusahaan teknologi berjiwa sosial yang bertujuan untuk meningkatkan kesejahteraan pekerja di berbagai sektor informal di Indonesia. Go-Jek lahir pada Agustus 2010, dengan pendiri Nadiem Makarim dan Michaelangelo Moran. Ide bisnis Go-Jek bermula dari obrolan Nadiem Makarim, dengan para tukang ojek langganannya, sehingga ia jadi memahami bahwa sebagian besar waktu tukang ojek banyak dihabiskan untuk mangkal dan menunggu penumpang, karena para tukang ojek biasanya bergiliran dengan tukang ojek lainnya untuk menarik penumpang. Selain itu terkadang penumpang juga sepi. Sementara dari sisi pengguna ojek, keamanan dan kenyamanan ojek belum terjamin. Melihat persoalan tersebut ia mendapatkan ide membuat inovasi tentang bagaimana cara orang bisa memesan ojek dengan mudah melalui telepon seluler tanpa harus repot ke pangkalan ojek, dan juga tentunya meningkatkan pendapatan para tukang ojek dengan konsep ekonomi-berbagi. 


\section{GO \\ An Ojek For Every Need}

Sumber: https://id.wikipedia.org

Gambar 1. Logo dan Tagline Go-Jek

Pada awalnya, Go-Jek mulai dengan 20 pengemudi dengan cara pemesanan masih melalui telepon, BBM dan Yahoo Messenger ke call center, kemudian operator call center akan mencari pengemudi Go-Jek terdekat, lalu menugaskan pengemudi untuk menjemput pelanggan sambil memantau kedatangan pengemudi dengan sistem navigasi dan koordinasi dengan pelanggan. Mengikuti perkembangan zaman yang semakin mengandalkan teknologi, pada tanggal 7 Januari 2015, Go-Jek pun meluncurkan aplikasi GoJek sebagai media yang mempertemukan konsumen dan pengemudi ojek.

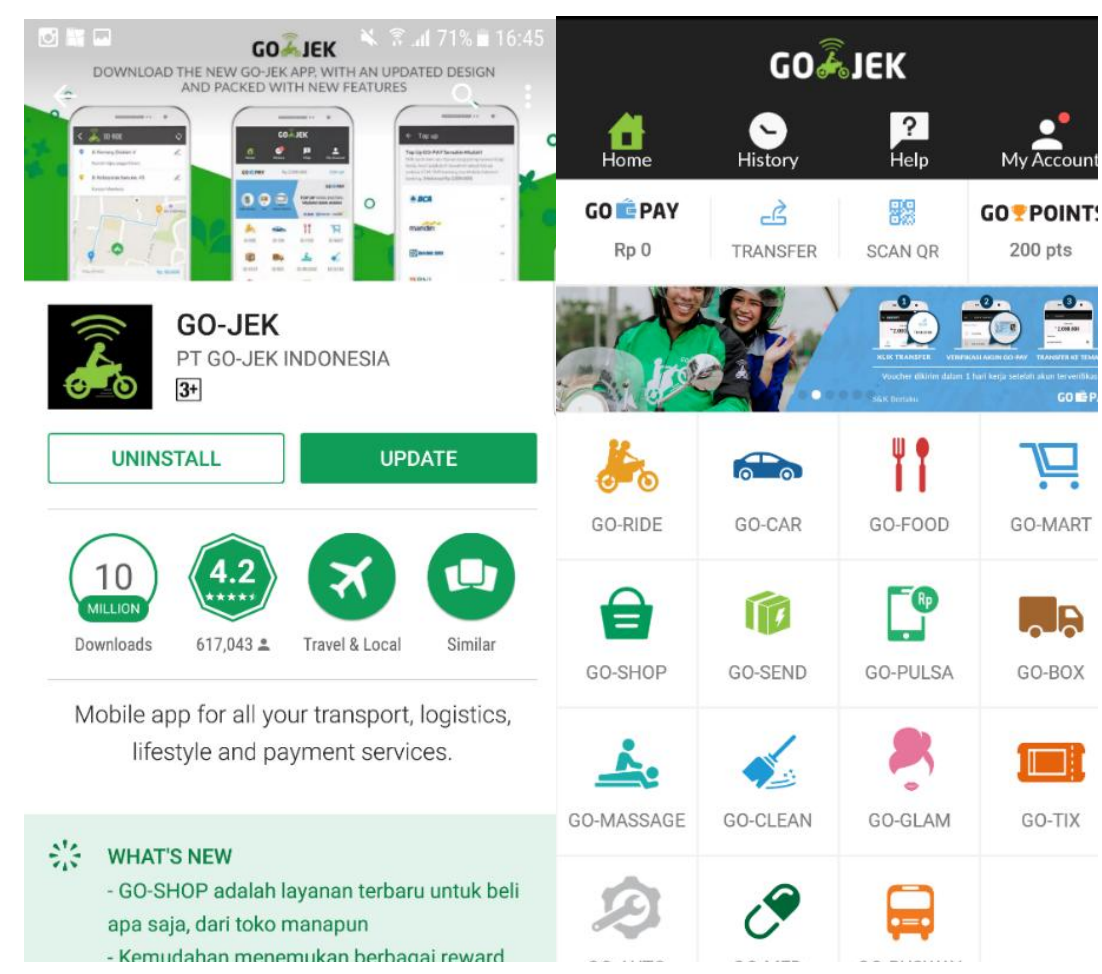

Sumber: Google Play

Gambar 2. Aplikasi Go-Jek 
Pada aplikasi Go-Jek saat ini terdapat lima belas jenis layanan, yaitu:

1. Go-Ride adalah layanan transportasi sepeda motor yang dapat mengantar penumpang ke berbagai tempat, lebih mudah dan lebih cepat.

2. Go-Car adalah layanan transportasi menggunakan mobil untuk mengantar penumpang kemanapun dengan nyaman.

3. Go-Food adalah layanan pesan antar makanan pertama di Indonesia dengan lebih dari 30.000 daftar restoran.

4. Go-Mart adalah layanan untuk berbelanja ribuan jenis barang dari berbagai macam toko.

5. Go-Shop adalah layanan belanja untuk membeli barang apapun dari toko manapun.

6. Go-Send adalah layanan kurir segera yang dapat digunakan untuk mengirim surat dan barang dalam waktu 60 menit.

7. Go-Pulsa adalah layanan pengisian pulsa langsung dari aplikasi Go-jek dengan menggunakan Go-Pay.

8. Go-Box adalah layanan pindah barang ukuran besar menggunakan truk bak atau mobil van tertutup.

9. Go-Massage adalah layanan jasa pijat kesehatan profesional langsung ke rumah pelanggan.

10. Go-Clean adalah layanan jasa kebersihan profesional untuk membersihkan kamar kos, rumah dan kantor.

11. Go-Glam adalah layanan jasa perawatan kecantikan untuk manicure-pedicure, cream bath, waxing, dan lainnya langsung ke rumah pelanggan.

12. Go-Tix adalah layanan informasi acara dengan akses pembelian dan pengantaran tiket langsung ke tangan pelanggan.

13. Go-Auto adalah layanan auto care, auto service, serta towing dan emergency untuk memenuhi kebutuhan otomotif.

14. Go-Med adalah layanan terpadu untuk mendapatkanobat-obat dengan resep dokter, vitamin, suplemen, dan kebutuhan medis lainnya yang terjamin keasliannya dengan cepat, aman dan nyaman.

15. Go-Busway adalah layanan untuk memonitor jadwal layanan bus TransJakarta dan memesan GoRide untuk mengantar Anda ke sana.

Selain itu juga ditambah dengan layanan pembayaran Go-Pay, layanan dompet virtual untuk transaksi pada aplikasi Go-Jek, serta satu layanan kerjasama Go-jek dengan Taksi Blue Bird yaitu Go-BlueBird, yang merupakan layanan pemesanan taksi Blue Bird melalui aplikasi Go-jek, serta program penghargaan pelanggan GoPoints untuk pelanggan yang menggunakan metode pembayaran GoPay.

Kegiatan Go-Jek bertumpu pada tiga nilai pokok: kecepatan, inovasi, dan dampak sosial. Selain itu Go-Jek memiliki janji nilai sebagai berikut:

1. Layanan transportasi, gaya hidup dan logistik di dalam satu aplikasi.

2. Transaksi mudah dan cashless dengan Go-Pay.

3. Penyimpanan alamat tujuan dan GPS yang tepat untuk proses pesan yang lebih cepat.

4. Harga yang transparan sebelum konfirmasi pemesanan.

5. Memantau pengemudi dengan foto dan informasi kontak. 
6. Sistem penilaian jasa untuk peningkatan berkelanjutan.

Model bisnis awal Go-Jek terbilang sangat sederhana, yakni berusaha menjawab persoalan yang dialami pelanggan untuk transportasi orang secara cepat dan murah. Dalam perkembangannya Go-Jek, dengan transportasi sebagai tulang punggung bisnis berkembang ke berbagai layanan lainnya dan menjelma menjadi layanan aplikasi satu pintu. Aplikasi Go-Jek membantu para pengemudi untuk mendapat akses kepada lebih banyak pelanggan.

Perkembangan mau pun inovasi model bisnis merupakan suatu langkah strategis bagi perusahaan, yang menjadi penentu langkah sukses atau tidaknya suatu perusahaan dalam persaingan bisnis yang saat ini menjadi semakin ketat untuk dapat tumbuh dan lestari. Model bisnis yang baru muncul mendesak model bisnis lama untuk berubah untuk mengikuti perkembangan jaman atau tergerus jaman.

Penemuan Internet dan inovasi teknologi, khususnya teknologi informasi dan digital mendorong perubahan yang pesat pada cara manusia berinteraksi dan berkomunikasi, demikian juga pada cara manusia berbisnis.Muncul gerakan ekonomi baru yang disebut ekonomi-berbagi (sharing economy) atau yang dikenal juga dengan sebutan ekonomi-kolaboratif atau ekonomi-bersama.

Konsep ekonomi-berbagi ini digunakan pada Go-jek, dimana Go-Jek mendayagunakan kepemilikan orang lain (kendaraan pengemudi) dalam pengadaan armada untuk memberikan layanan yang lebih luas dengan memanfaatkan kapasitas menganggur dari sepeda motor atau mobil (aset) maupun pengemudi (jasa), sama seperti yang dilakukan oleh pesaing Go-jek yaitu Grab maupun Uber. Transaksi dalam lingkup kelompok pemilik kendaraan yang masih memiliki kapasitas menganggur dengan pelanggan yang membutuhkan dalam aplikasi Gojek menjadi bentuk ekonomi-berbagi, dimana terjadi pembagian manfaat ekonomi dari pengemudi, pelanggan serta Go-jek sebagai pemilik aplikasi yang menghubungkan antara penyedia jasa dan pelanggan, termasuk mempermudah hubungan antara berbagai penyedia jasa yang ada dalam aplikasi Go-jek seperti: ojek, perawatan kecantikan, pijat, dan lain-lain. Dalam hal ini pengemudi dan penyedia jasa lain mendapatkan manfaat dengan meningkatnya kesempatan dan kemudahan untuk mendapatkan pelanggan dengan adanya aplikasi yang memudahkan komunikasi dan terjadinya transaksi, dan pelanggan mendapatkan akses yang mempermudah pemenuhan kebutuhan serta harga yang bersaing, sementara bagi Go-jek selaku pemilik aplikasi mendapatkan persentase keuntungan dari transaksi yang ada.

Grab didirikan pada tahun 2012 oleh Anthony Tan and Tan Hooi Lin yang berbasis di Singapura. Grab awalnya diluncurkan sebagai GrabTaxi dengan sebutan MyTeksi di Malaysia. Grab masuk ke Indonesia dengan membawa bendera PT Solusi Transportasi Indonesia, dengan dukungan modal antara lain dari $G G V$ Capital, Soft Bank dan Grup Lippo pada Juni 2014. Grab beroperasi di 6 negara di Asia Tenggara yaitu: Malaysia, Filipina, India, Singapura, Thailand, Vietnam, dan Indonesia.

Uber didirikan pada tahun 2009 di San Fransisco oleh Travis Kalanick dan Garrett Camp. Uber saat ini beroperasi di lebih dari 66 negara dan 507 kota. Uber masuk ke Indonesia 
dengan bendera perusahaan Uber Asia Limited pada Agustus 2014.

Perkembangan Go-Jek di

Indonesia melampaui pesaingnya, yaitu : Grab maupun Uber, baik dari jumlah pengemudi maupun jenis layanan.Go-Jek mengalami transformasi model bisnis dari yang semula hanya sebagai model bisnis transportasi ojek hingga menjadi model bisnis layanan aplikasi satu pintu dalam prinsip ekonomi-berbagi. Go-Jek memiliki keunggulan-kompetitif yang diperlukan untuk unggul di pasar. Pengaruh transformasi model bisnis GoJek dalam menghasilkan kelestarian keunggulan-kompetitif perusahaan.

Berdasarkan latar belakang yang telah diuraikan di atas, maka dapat dirumuskan masalah penelitian sebagai berikut: "Transformasi model bisnis GoJek untuk keunggulan-kompetitif dalam perkembangan ekonomi-berbagi dari sudut pandang pelanggan."

Hal inilah yang mendorong penelitian ini, yaitu untuk memahami persoalan-persoalan sebagai berikut:

1. Apakah transformasi model bisnis Go-jek efektif menghasilkan kelestarian keunggulan-kompetitif;

2. Apakah transformasi model bisnis Go-jek efektif menghasilkan nilai pelanggan yang tinggi;

3. Apakah peningkatan nilai pelanggan yang dihasilkan dari transformasi model bisnis Go-jek meningkatkan nilai tambah Gojek;

4. Apakah peningkatan nilai tambah Go-jek melestarikan keunggulankompetitif Go-jek, khususnya dalam prinsip ekonomi-berbagi dari sudut pandang pelanggan.

Manfaat yang didapat dari penelitian ini diharapkan dapat memberikan kontribusi teoritis, yaitu memperkaya bukti empiris bahwa model bisnis mendukung perkembangan bisnis dan melestarikan keunggulan-kompetitif perusahaan, serta kontribusi praktis, yaitu memberikan gambaran tentang model bisnis Go-jek serta transformasinya yang dapat menjadi acuan bagi perusahaan rintisan dalam mengembangkan perusahaan dalam ekonomi-berbagi.

\section{TINJAUAN PUSTAKA}

Transformasi sebagai perubahan rupa (bentuk, sifat, fungsi, dan sebagainya). Perubahan dilakukan dengan cara memberi tanggapan terhadap pengaruh unsur eksternal dan internal dari organisasi yang akan mengarahkan perubahan dari bentuk yang sudah dikenal sebelumnya menjadi suatu bentuk yang baru. Lewin (Purhantara, 2009) menyatakan perubahan terjadi karena munculnya tekanan-tekanan terhadap organisasi, individu, atau kelompok. Lippit (Nursalam, 2001) mendefinisikan perubahan sebagai sesuatu yang direncanakan atau tidak direncanakan terhadap status quo dalam individu, situasi atau proses.

Berdasarkan uraian di atas dapat disimpulkan bahwa transformasi adalah suatu perubahan dari suatu bentuk awal menjadi bentuk yang lain, yang direncanakan mau pun tidak direncanakan, serta dapat terjadi secara lambat mau pun cepat dan berkesinambungan. Transformasi bisnis adalah seluruh proses perubahan yang dilakukan oleh suatu korporasi untuk memosisikan diri agar lebih baik dalam menyikapi dan menjawab tantangantantangan bisnis baru, lingkungan usaha yang berubah secara cepat maupun keinginan-keinginan baru yang muncul dari dalam perusahaan. Perubahan dilakukan secara menyeluruh dan berkesinambungan terhadap pola pikir, pola pandang dan pola tindak perusahaan, strategi bisnis, budaya 
perusahaan maupun perilaku dan kemampuan organisasi.

Johnson et al. (2008) menyatakan bahwa model bisnis terdiri dari 4 elemen, yaitu: janji nilai pelanggan, formula keuntungan, sumber daya utama, dan proses utama, yang saling terkait secara bersamaan menciptakan dan menghantarkan nilai. Osterwalder dan Pigneur (2010) mengemukakan bahwa sebuah model bisnis menggambarkan dasar pemikiran tentang bagaimana organisasi menciptakan, memberikan dan menangkap nilai. Model bisnis ibarat cetak biru sebuah strategi yang diterapkan melalui struktur organisasi, proses, dan sistem.
Kotler dan Keller (2009) menyatakan bahwa nilai pelanggan merupakan kombinasi kualitas, layanan, harga dari suatu tawaran produk. Nilai terhantar pada pelanggan adalah selisih antara jumlah nilai bagi pelanggan dan jumlah biaya dari pelanggan, dan jumlah nilai bagi pelanggan adalah sekelompok keuntungan yang diharapkan pelanggan dari barang atau jasa tertentu. Menjadi tujuan bagi perusahaan untuk menciptakan nilai tambah, tidak hanya untuk memberikan nilai kepada pelanggan, namun pada akhirnya nilai itu akan kembali pada perusahaan dalam bentuk penjualan dan laba.

Tabel 1. Model Bisnis menurut Ahli

\begin{tabular}{|c|c|c|}
\hline Penulis / Tahun & Definisi Model Bisnis & Komponen Model Bisnis \\
\hline $\begin{array}{l}\text { Gassmann et al. } \\
\text { (2016) }\end{array}$ & $\begin{array}{l}\text { Model bisnis memberikan gambaran } \\
\text { menyeluruh tentang cara yang dilakukan } \\
\text { oleh sebuah perusahaan untuk menciptakan } \\
\text { dan nenentukan nilai, dengan terlebih dulu } \\
\text { menentukan } 4 \text { (empat) dimensi bisnisnya, } \\
\text { yaitu siapa, apa, bagaimana, dan mengapa. }\end{array}$ & 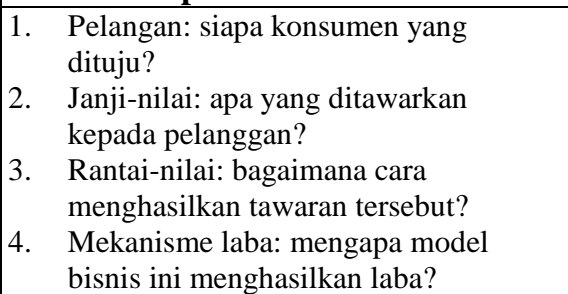 \\
\hline Afuah (2004) & $\begin{array}{l}\text { Model bisnis adalah sebuah rerangka kerja } \\
\text { untuk menghasilkan uang; serangkaian } \\
\text { aktivitas yang dilakukan perusahaan, } \\
\text { bagaimana perusahaan melakukannya, dan } \\
\text { kapan perusahaan melakukannya sehingga } \\
\text { dapat menawarkan manfaat pelanggan yang } \\
\text { diinginkan dan untuk mendapatkan } \\
\text { keuntungan. }\end{array}$ & $\begin{array}{ll}\text { 1. } & \text { Nilai pelanggan (customer value) } \\
\text { 2. } & \text { Cakupan (scope) } \\
\text { 3. } & \text { Penetapan harga (pricing) } \\
\text { 4. } & \text { Sumber pendapatan (revenue source) } \\
\text { 5. } & \text { Aktivitas yang saling terhubung } \\
& \text { (connected activities) } \\
\text { 6. Implementasi (implementation) } \\
\text { 7. Kemampuan (capabilities) } \\
\text { 8. } \\
\text { Kelestarian (sustainabilities) } \\
\end{array}$ \\
\hline $\begin{array}{ll}\text { Osterwalder } & \text { dan } \\
\text { Pigneur }(2010) & \end{array}$ & $\begin{array}{l}\text { Model bisnis adalah dasar pemikiran } \\
\text { tentang bagaimana organisasi menciptakan, } \\
\text { memberikan dan menangkap nilai bagi } \\
\text { perusahaan, pelanggan dan masyarakat, } \\
\text { yang diterapkan dalam struktur organisasi, } \\
\text { proses dan sistem untuk menghasilkan } \\
\text { keuntungan dan aliran pendapatan yang } \\
\text { berkelanjutan. }\end{array}$ & $\begin{array}{l}\text { 1. Segmen pelanggan (customer } \\
\text { segments) } \\
\text { 2. Janji nilai (value proposition) } \\
\text { 3. Saluran (channels) } \\
\text { 4. Keterhubungan pelanggan (customer } \\
\text { relationship) } \\
\text { 5. Arus pendapatan (revenue streams) } \\
\text { 6. Sumber daya utama (key resources) } \\
\text { 7. Aktivitas utaman (key activities) } \\
\text { 8. Kemitraan utama (key partnerships) } \\
\text { 9. Struktur biaya (cost structure) }\end{array}$ \\
\hline $\begin{array}{l}\text { Chesbrough dan } \\
\text { Rosenbloom (2002) }\end{array}$ & $\begin{array}{l}\text { Model bisnis adalah metode dalam } \\
\text { melakukan bisnis, di mana sebuah } \\
\text { perusahaan dapat berdiri sendiri, yang pada } \\
\text { akhirnya dapat menghasilkan pendapatan, } \\
\text { merinci bagaimana sebuah perusahaan } \\
\text { menghasilkan uang dengan menentukan di } \\
\text { mana posisi dalam rantai nilai. }\end{array}$ & $\begin{array}{l}\text { 1. Pasar (market) } \\
\text { 2. Janji-nilai (value proposition) } \\
\text { 3. Rantai-nilai (value chain) } \\
\text { 4. Biaya dan keuntungan (cost and profit) } \\
\text { 5. Jejaring nilai (value network) } \\
\text { 6. Strategy kompetitif (competitive } \\
\text { strategy) }\end{array}$ \\
\hline
\end{tabular}




\begin{tabular}{|c|c|c|}
\hline Penulis / Tahun & Definisi Model Bisnis & Komponen Model Bisnis \\
\hline $\begin{array}{l}\text { Johnson et } \quad \text { al. } \\
(2008)\end{array}$ & $\begin{array}{l}\text { Model bisnis terdiri dari } 4 \text { elemen yang } \\
\text { saling terkait secara bersamaan } \\
\text { menciptakan dan menghantarkan nilai }\end{array}$ & $\begin{array}{l}\text { 1. Janji-nilai pelanggan (customer value } \\
\text { proposition) } \\
\text { 2. Formula keuntungan (profit formula) } \\
\text { 3. Sumber daya utama (key resources) } \\
\text { 4. Proses utama (key processes) }\end{array}$ \\
\hline $\begin{array}{l}\text { Tim PPM } \\
\text { Manajemen } \\
\text { (Permana, 2013) }\end{array}$ & $\begin{array}{l}\text { Model bisnis adalah gambaran hubungan } \\
\text { antara keunggulan dan sumber daya yang } \\
\text { dimiliki perusahaan, serta kegiatan-kegiatan } \\
\text { yang dilakukan untuk mengakuisisi dan } \\
\text { menciptakan nilai yang membuat } \\
\text { perusahaan mampu menghasilkan laba. }\end{array}$ & $\begin{array}{l}\text { 1. Keunggulan } \\
\text { 2. Sumber daya } \\
\text { 3. Kegiatan } \\
\text { 4. Nilai } \\
\text { 5. Laba }\end{array}$ \\
\hline
\end{tabular}

Sumber: Gassmann et al., Afuah, Osterwalder dan Pigneur, Chesbrough dan Rosenbloom, Johnson et al., Permana.

Botsman dan Rogers (2010) mendefinisikan ekonomi-berbagi sebagai sebuah sistem ekonomi berdasarkan pada berbagi aset atau jasa yang kurang dimanfaatkan, secara gratis atau untuk biaya, langsung dari individu. Ekonomi-berbagi merupakan penciptaan kembali perilaku pasar tradisional, yaitu: sewa, pinjaman, bertukar, berbagi, barter, dan memberi. Hal ini dimungkinkan dengan adanya teknologi, sehingga berlangsung dengan cara dan pada skala yang tidak mungkin terjadi sebelum Internet. Pertumbuhan teknologi mobile menyediakan platform untuk mengaktifkan teknologi GPS berbasis lokasi dan juga menyediakan kemudahan berbagi secara real-time.

Hamari et al., (2015) mengatakan bahwa ekonomi-berbagi adalah aktivitas memperoleh, memberikan atau membagikan akses terhadap barang dan jasa antar individu dengan individu lainnya yang dikoordinasikan melalui layanan daring berbasis komunitas yang menjadi pilihan yang menarik bagi konsumen. Ekonomiberbagi menurut Annisawati (2015) adalah sebuah konsep bisnis yang memberikan akses terhadap sumber daya yang dimiliki perorangan atau perusahaan untuk dimanfaatkan ataupun dikonsumsi bersama dengan orang lain. Ekonomi-berbagi itu sendiri muncul dengan dilatarbelakangi oleh kesadaran untuk melakukan efisiensi sumber daya dengan melakukan konsumsi secara bersama-sama.

Koopman et al. (2015) menyatakan bahwa ekonomi-berbagi menciptakan nilai dengan lima cara:
- Memberikan orang kesempatan untuk menggunakan barang milik orang lain, seperti: mobil, dapur,apartemen, dan properti lainnya; memungkinkan memanfaatkan aset yang kurang dimanfaatkan, atau "modal mati" untuk digunakan dengan lebih produktif

- Menyatukan beberapa pembeli dan penjual; membuat kedua sisi penawaran dan sisi permintaan pasar menjadi lebih kompetitif dan memungkinkan spesialisasi yang lebih besar.

- Menurunkan biaya untuk menemukan pedagang yang bersedia, ketentuan tawarmenawar, dan pemantauan kinerja; memotong biaya transaksi dan memperluas ruang lingkup perdagangan.

- Menggabungkan ulasan konsumen masa lalu dan produsen, serta menempatkan mereka di ujung jari pelaku pasar baru; dapat secara berarti mengurangi masalah informasi yang tidak berimbang antara produsen dan konsumen.

- Menawarkan pelarian terakhir di antara para pembuat kebijakan yang terperangkap oleh produsen yang ada; memungkinkan pemasok untuk menciptakan nilai bagi pelanggan yang lama tidak 
terlayani oleh para petahana yang telah menjadi tidak efisien dan tidak tanggap karena peraturan perlindungan mereka.

Ekonomi-berbagi memperluas akses ke produk, layanan dan bakat lebih dari satu untuk satu, atau kepemilikan tunggal. Perusahaan, individu dan pemerintah semua aktif berpartisipasi sebagai pembeli, penjual, pemberi pinjaman atau peminjam di dalam ekonomi-berbagi. Ekonomi-berbagi dapat disarikan sebagai sebuah konsep bisnis yang memberikan akses terhadap sumber daya yang dimiliki perorangan atau perusahaan untuk dimanfaatkan ataupun dikonsumsi bersama dengan orang lain, dengan tujuan untuk optimalisasi sumber daya dengan melakukan konsumsi secara bersama-sama.

Menurut Porter (Silaban, 2006), strategi bersaing adalah pendekatan yang dilakukan untuk mengungguli pesaingpesaingnya dalam industri, arena fundamental tempat persaingan terjadi. Kotler (2001) menyatakan strategi yang secara kuat memosisikan perusahaan terhadap pesaing dan yang memberi perusahaan keunggulan-kompetitif yang sekuat mungkin. Dapat diartikan bahwa strategi bersaing adalah upaya perusahaan untuk menang dari pesaingnya di pasar dengan memanfaatkan keunggulankeunggulannya.

Menurut Coyne (Utama, 2009), keunggulan-kompetitif mempunyai arti hanya bila "dirasakan" di pasar. Barney (Utama, 2009), mengemukakan keunggulan tersebut akan berkelanjutan, hanya bila para pesaing tidak bisa dengan mudah meniru, artinya ada perbedaan mendasar yang memisahkan perusahaan dari pesaing. Apabila tidak demikian, maka keunggulankompetitif tidak ada. Hal terpenting dalam mempertahankan keunggulan adalah bahwa para pesaing yang ada dan pesaing potensial tidak mampu atau tidak akan mengambil tindakan untuk meniru ataupun menyaingi perusahaan. Apabila para pesaing dapat meniru dan menyaingi perusahaan, maka perusahaan tidak memiliki keunggulankompetitif.
Barney (Utama,

2009)

mengemukakan empat kondisi yang harus dipenuhi sebelum suatu sumber daya dapat disebut sebagai sumber keunggulankompetitif berkelanjutan:

1. Berharga (valuable), merupakan sumber daya keorganisasian yang sangat berharga, terutama dalam kaitannya dengan kemampuan untuk mengekploitasi kesempatan dan/atau menetralisir ancaman dari lingkungan perusahaan.

2. Langka (rarity), relatif sulit untuk dikembangkan, sehingga menjadi langka di lingkungan bersaing.

3. Sulit ditiru (inimitable), sangat sulit untuk ditiru oleh pesaing.

4. Tidak mudah digantikan (nonsubstitutable)

Gassmann et al. (2016) menyatakan bahwa keunggulan-kompetitif sebuah perusahaan di masa depan tidak ditentukan oleh produk dan proses yang inovatif, tetapi ditentukan oleh model bisnis yang inovatif. Berdasarkan berbagai uraian yang dikemukan, maka dapat disimpulkan bahwa keunggulan-kompetitif adalah serangkaian kemampuan yang berharga, langka, sulit ditiru dan digantikan, yang dimiliki dan memberikan keunggulan dibanding para pesaing, serta memberikan nilai kepada pelanggan.

\section{METODE PENELITIAN}

Penelitian ini menggunakan desain penelitian kualitatif dengan studi kasus dan jenis penelitian deskriptif.

Bogdan dan Taylor (1992) menjelaskan bahwa penelitian kualitatif adalah salah satu prosedur penelitian yang menghasilkan data deskriptif berupa ucapan atau tulisan dan perilaku orang-orang yang diamati.

Creswell (2009) menyatakan studi kasus merupakan penelitian di mana di dalamnya peneliti menyelidiki secara cermat suatu program, peristiwa, aktivitas, dan 
peneliti mengumpulkan informasi secara lengkap dengan menggunakan berbagai prosedur pengumpulan data berdasarkan waktu yang telah ditentukan. Studi kasus memberikan keunggulan dalam hal mampu mengungkap hal-hal yang spesifik, unik dan rinci.

Penelitian deksriptif adalah penelitian yang menggambarkan suatu fenomena. Fenomena tersebut dapat berupa aktivitas, perubahan, hubungan, persamaan, atau perbedaan dengan fenomena yang lainnya. Penelitian deskriptif digunakan karena dapat menggambarkan suatu gejala sosial. Sekaran dan Bougie (2013) menyatakan bahwa penelitian deskriptif sering didesain untuk mengumpulkan data yang dapat menggambarkan karakteristik dari orang, kejadian atau situasi.

Wilayah Penelitian adalah Jakarta, karena merupakan pangkalan awal pendirian Go-jek dan Jakarta sebagai area operasi dan penggunaan Go-Jek terbesar sehingga dapat memberikan gambaran terhadap studi kasus dari penelitian ini. Sumber data untuk penelitian ini adalah data primer dan data sekunder. Data primer merupakan data yang langsung dikumpulkan pada saat melakukan penelitian yaitu berupa rekaman wawancara dan pengamatan langsung. Selain itu data sekunder adalah data dalam bentuk publikasi, laporan, dokumen, buku-buku serta berita yang berkaitan dengan penelitian ini.

Informan adalah insan yang dimanfaatkan untuk memberikan informasi tentang situasi dan kondisi latar penelitian, ia harus mempunyai banyak pengalaman tentang latar penelitian menurut Moleong (Purnamasari, 2008:62). Informan dalam penelitian ini adalah individu pelanggan Gojek.

Metode pengumpulan data dalam penelitian ini menggunakan wawancara mendalam semi-terstruktur, observasi dan data sekunder. Pengumpulan data dengan wawancara mendalam (in-depth interview), merupakan salah satu teknik wawancara yang mampu menyediakan rincian informasi yang lebih banyak dan gambaran yang lebih lengkap mengenai suatu informasi dibandingkan teknik lainnya (Boyce \& Neale, 2006). Selain wawancara, peneliti juga melakukan observasi ketika wawancara dilakukan untuk melengkapi informasi yang diperoleh melalui pengamatan terhadap perilaku, sikap dan bahasa non verbal subyek ketika sedang melakukan wawancara.Sekaran dan Bougie (2013) menyatakan observasi adalah sebagai suatu teknik secara terencana untuk melihat, merekam, menganalisis dan menginterpretasikan perilaku, tindakan atau kejadian.

Penelitian ini menggunakan prinsip triangulasi dengan data sekunder dari berbagai tulisan, seperti berita, buku, jurnal dan penelitian lainnya yang terkait, serta materi dari Internet, seminar, dan lain-lain yang dapat mendukung penelitian ini. Moleong (2010), menyatakan triangulasi adalah teknik pemeriksaan keabsahan data yang memanfaatkan sesuatu yang lain di luar data itu untuk keperluan pengecekan atau sebagai pembanding terhadap data itu. Pada saat pengambilan data menggunakan metode wawancara, peneliti akan membutuhkan pedoman wawancara dan alat perekam. Alat perekam digunakan peneliti untuk menjaga ketepatan data penelitian dan digunakan dengan seijin subyek penelitian.

Langkah-langkah penelitian yang dilakukan:

1. Membuat pedoman wawancara.

2. Memilih informan

3. Menjelaskan latar belakang penelitian

4. Pengumpulan data

5. Intisari data

6. Penyajian data

7. Penarikan simpulan

Dalam menganalisis, peneliti menggunakan penalaran induktif, dengan memulai pengamatan dari fenomena yang terjadi terkait Go-Jek untuk menarik suatu simpulan yang diharapkan dapat berguna untuk memberikan penjelasan yang lebih mendalam tentang nilai tambah dan manfaat model bisnis dan transformasi Go-jek pada situasi saat ini. Suriasumantri (2001) mengemukakan bahwa penalaran induktif merupakan cara berpikir dimana ditarik suatu simpulan yang bersifat umum dari berbagai kasus yang bersifat individual. 
Ihalauw (2016:5) memaparkan bahwa situasi problematik bisa bersumber pada celahcelah (gaps) teori-teori yang telah ada, hasilhasil penelitian terdahulu yang disajikan dalam laporan penelitian dan jurnal-jurnal ilmiah, atau bersumber pada fakta, peristiwa, objek atau fenomena empirik. Ihalauw (2016:2) menyatakan bahwa sasaran akhir dari penelitian kualitatif dengan pendekatan induktif ialah: membangun teori mini. Jonker dan Pennink (Ihalauw, 2016) mengartikan teori mini sebagai teori yang berlaku untuk satu situasi tertentu, di mana teori mini masih perlu dibuktikan validitas umumnya. Dengan mengulangi penelitian, teori mini dapat berkembang menjadi teori yang berguna dalam berbagai situasi dan pada masa-masa tertentu: sebuah teori dasar (grand theory).

\section{HASIL DAN PEMBAHASAN}

Hasil penelitian ini diperoleh dengan wawancara mendalam semi-terstruktur, observasi dan data sekunder lain yang diperoleh penulis selama penelitian ini. Wawancara ini dilakukan dengan wawancara tatap muka secara langsung dan melalui telepon pada kurun waktu April Mei 2017, sehingga kebaruan data terpenuhi. Jumlah informan yang diwawancarai sebanyak 6 orang.

Penelitian ini tidak menitik beratkan pada pendalaman definisi ekonomi-berbagi yang saat ini masih dikritisi oleh beberapa pakar. Ekonomi-berbagi pada penelitian ini lebih untuk menjelaskan bagaimana awal mula konsep bisnis Go-jek lahir dan berkembang seperti yang dijelaskan pada bagian pendahuluan. Go-jek lahir atas pemikiran pendiri Go-jek untuk memanfaatkan kapasitas menganggur dari para pengemudi Go-jek dengan mempertemukannya dengan kebutuhan pelanggan serta perluasaan pada bidang jasa lainnya.

\section{Persoalan Penelitian 1: Apakah transformasi model bisnis Go-jek efektif menghasilkan kelestarian keunggulan-kompetitif?}

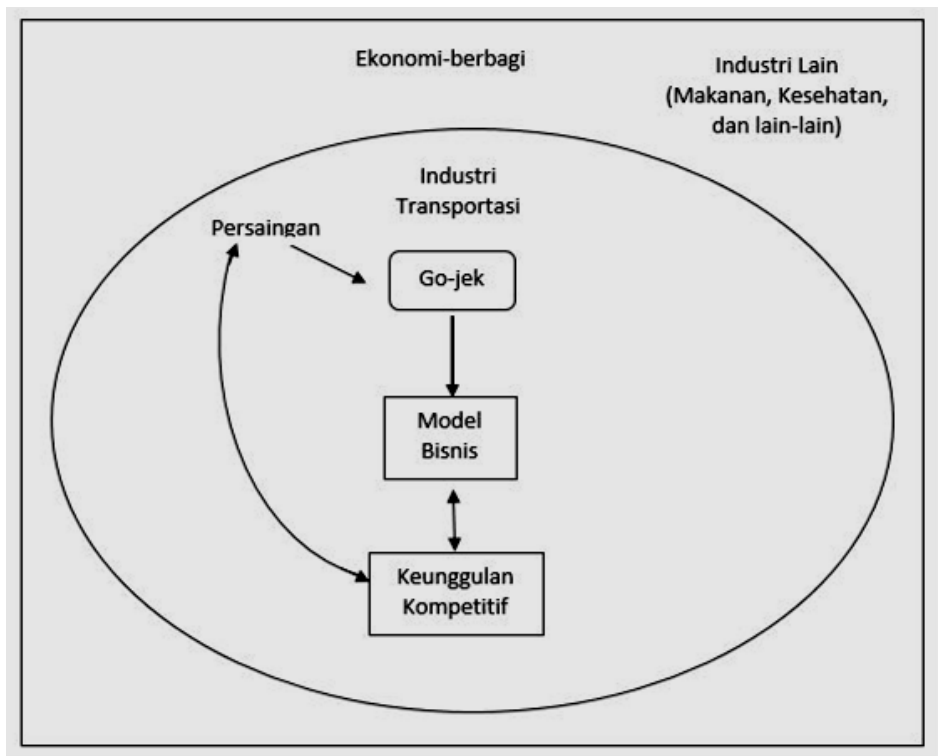

Sumber: Model Penelitian

Gambar 3. Model Bisnis Awal Go-Jek

Model bisnis awal Go-Jek adalah pada industri transportasi, yaitu melayani transportasi orang secara cepat dan murah, dengan menggunakan call center Go-jek menawarkan penyediaan jasa transportasi ojek untuk memenuhi kebutuhan pelanggan akan alat transportasi yang cepat, murah dan aman. 


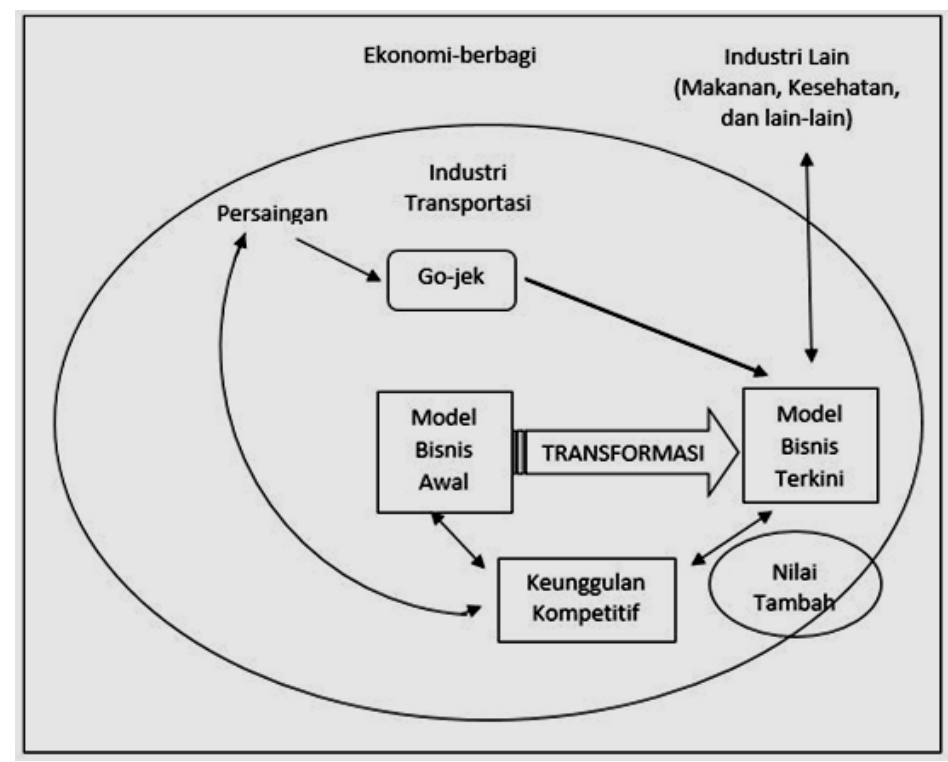

Sumber: Model Penelitian

Gambar 4. Model Bisnis Terkini Go-Jek (setelah transformasi)

Dalam perkembangannya Go-Jek, dengan transportasi sebagai tulang punggung bisnis berkembang ke berbagai layanan sebagai layanan aplikasi satu pintu. Transformasi Go-Jek ini merupakan perwujudan inovasi terus-menerus yang dilakukan Go-Jek, tidak hanya untuk menjawab tantangan yang timbul karena pesaingan (Grab, Uber) dan peluang yang ada di pasar, namun juga menunjukkan kejelian Go-Jek dalam melakukan pengembangan produk, jasa dan bakat yang dimiliki (sumber daya utama / key resources). Selain itu Go-Jek terus melakukan upaya-upaya perbaikan, seperti dengan pemberlakuan sistem penilaian pengemudi dan percepatan proses pembayaran kepada pengemudi (proses utama / key processes), di mana hal ini untuk meningkatkan kualitas layanan pada pelanggan sekaligus memenuhi janji-nilai Go-Jek kepada pelanggan (customer value proposition) yaitu "An Ojek for Every Need", yang pada ujungnya akan berpengaruh pada keuntungan perusahaan (profit formula).

Informasi dari nara-sumber yang diwawancarai secara mendalam dapat diringkas sebagai berikut:

a. Transformasi model bisnis Gojek dari hanya ojek daring menjadi aplikasi dengan banyak layanan mengubah konsep bisnis Go-jek.

b. Transformasi model bisnis yang dilakukan Go-jek efektif karena adanya nilai yang dirasakan pelanggan.

c. Keunggulan yang dimiliki Go-jek dibanding pesaingnya yang bernilai bagi pelanggan adalah :

1. Satu aplikasi dengan banyak layanan

2. Pengemudi yang banyak

3. Harga yang pantas

4. Go-Pay +

5. Go-Points

d. Tranformasi model bisnis Gojek efektif menghasilkan keunggulan kompetitif.

Seperti diungkapkan Ansoff (1957), bahwa ada 4 strategi pertumbuhan, yaitu:

1. Penetrasi pasar (market penetration)

Pada awal penetrasi pasar Go-jek menggunakan layanan call center, namun dengan perkembangan teknologi yang 
pesat maka Go-jek beralih menjadi aplikasi daring.

2. Pengembangan pasar (market development)

Pada saat awal mengerjakan penelitian ini jumlah kota di Indonesia yang dilayani Go-jek baru mencapai 10 kota, dalam waktu tidak sampai satu tahun. Saat ini (5 Mei 2017) jumlah kota yang dilayani Go-jek mencapai 25 kota. Hal ini menunjukkan pengembangan pasar Go-jek yang pesat.

3. Pengembangan produk (product development)

Pada awalnya Go-jek hanya merupakan ojek daring. Namun saat ini Go-jek telah beralih menjadi aplikasi layanan satu pintu dengan 18 layanan yang sebagian besar bertumpu pada layanan transportasi.

4. Diversifikasi (diversification)

Saat ini Go-jek masih berfokus pada layanan transportasi, namun untuk diversifikasi produk tentunya merupakan peluang strategis perusahaan.

\section{Persoalan Penelitian 2: Apakah transformasi model bisnis Go-jek efektif menghasilkan nilai pelanggan yang tinggi? \\ Data lapangan yang diperoleh dari para informan kunci dapat diringkas sebagai berikut: Transformasi model bisnis Go-jek dari hanya ojek daring menjadi aplikasi dengan banyak layanan memberikan nilai pelanggan yang tinggi, yaitu: \\ 1. Terpenuhinya kebutuhan yang beragam (dalam satu aplikasi) \\ 2. Kemudahan \\ 3. Efisiensi waktu \\ 4. Efisiensi biaya}

Persoalan Penelitian 3: Apakah peningkatan nilai pelanggan yang dihasilkan dari transformasi model bisnis Go-jek, meningkatkan nilai tambah Gojek?

a. Nilai pelanggan yang dihasilkan dari transformasi model bisnis Go-jek memberikan nilai tambah bagi Go-jek, karena layanan yang beragam dalam satu aplikasi, kemudahan serta efisiensi waktu dan biaya meningkatkan penggunaan aplikasi Go-jek, yang berarti meningkatkan penjualan Go-jek.

b. Semakin tinggi nilai pelanggan yang dihasilkan Go-jek dari transformasi model bisnisnya, maka semakin tinggi nilai tambah yang didapat Go-jek.

c. Nilai tambah ini membuat Go-jek dinilai lebih unggul dari pesaingnya oleh pelanggan.

\section{Persoalan Penelitian 4: Apakah peningkatan nilai tambah Go-jek, melestarikan keunggulan- kompetitif Go- jek?}

Semakin tinggi nilai tambah yang didapat Go-jek dari transformasi model bisnis, maka semakin lestari keunggulan kompetitif Go-jek. Hal ini dikarenakan kemampuan unik yang dimiliki Go-jek lebih unggul dari pesaing dan memenuhi unsur VRIN, yaitu:

1. Berharga (valuable)

2. Langka (rarity)

3. Sulit ditiru (inimitable)

4. Tidak mudah digantikan (nonsubstitutable)

Lagi pula, kemampuan unik tersebut dpat Go-jek kerahkan dalam mengoperasikan model-bisnis yang telah bertransformasi. Kenyataan ini sejalan dengan pendapat Carpenter dan Sanders (2009) bahwa selain berkarakteristik VRIN, kemampuan unik itu harus dapat dikerahkan (exploitable). 
Meniru langkah pesaing dalam hal aktivitas pemasaran sering dilakukan oleh perusahaan yang sejenis, namun untuk dapat unggul dari pesaing tidak cukup hanya melakukan hal yang sama yang dilakukan oleh pesaing, atau melakukan hal yang dilakukan pesaing secara lebih baik. Diperlukan suatu sinergi atau rantai nilai yang menghubungkan keseluruhan aktivitas perusahaan dengan baik, hingga sampai pada pelanggan. Dalam hal ini strategi dan aktivitas yang dilakukan Go-jek berharga (valuable), langka (rarity), sulit ditiru (inimitable), dan tidak mudah digantikan (nonsubstitutable) oleh pesaing. Hal ini membuat Go-jek memiliki keunggulankompetitif dari pesaingnya. Semakin baik Go-jek menciptakan nilai bagi pelanggannya, maka semakin besar pula nilai tambah yang dihasilkan, yang pada akhirnya melestarikan keunggulan-kompetitf bagi Go-jek.

Selain itu, dari penelitian ini ada beberapa hal tambahan yang menarik untuk dicermati dan diringkas seperti berikut ini:

a. Selain Transportasi, yang menjadi layanan utama Go-jek, Go-Food menjadi layanan yang banyak digunakan pelanggan.

b. Masih ada beberapa layanan yang dapat ditambahkan pada Go-jek berdasarkan ide dari kebutuhan masing-masing informan, seperti:

- Go-Member, layanan antarjemput langganan (mingguan/ bulanan)

- Go-Book, layanan beli buku

- Go-Pet, layanan hewan peliharaan

- Share-link lokasi pelanggan, yang dapat meningkatkan kepastian dan rasa aman karena posisi pelanggan dapat diketahui.

c. Hal-hal yang masih perlu dikembangkan/diperbaiki oleh Go-jek, yaitu

- Aplikasi

- Pengemudi

\section{- Distribusi tutup hidung dan tutup kepala}

Temuan-temuan tersebut diharapkan dapat menjadi saran dalam perbaikan atau pun pengembangan Go-jek. Ada pun dalam penelitian ini juga ditemukan serendipity effect, yaitu penemuan yang tidak disengaja terkait bahwa keberadaan Go-jek telah berdampak dan mengubah kehidupan pelanggan Go-jek, menjadi lebih mandiri.

\section{Deskripsi Model Bisnis}

Model bisnis adalah gambaran keterkaitan dari sumber daya utama yang dimiliki serta proses utama yang dilakukan perusahaan dalam suatu rantai nilai untuk menciptakan dan menghantar nilai kepada pelanggan dalam upaya menghasilkan laba, sehingga komponen model bisnis ada 5 , yaitu:

1. Sumber daya utama (key resources)

2. Proses utama (key processes)

3. Rantai nilai (value chain)

4. Janji-nilai pelanggan (customer value proposition)

5. Formula keuntungan (profit formula)

Deskripsi ini dibentuk berdasarkan pengembangan konsep model bisnis menurut Johnson et al. (2008) yang terdiri dari 4 elemen, yaitu:

1. Janji nilai pelanggan (customer value proposition),

2. Formula keuntungan (profit formula),

3. Sumber daya utama (key resources),

4. Proses utama (key processes), yang saling terkait secara bersamaan menciptakan dan menghantarkan nilai.

Mengingat pandangan Porter (Gassmann et al., 2016) yang menyatakan bahwa pesaing akan lebih kesulitan menyamai aktivitas yang saling terhubung ketimbang sekadar menyamai pendekatan penjualan, menyamai teknologi pemrosesan, 
atau meniru fitur-fitur produk perusahaan, maka penambahan rantai-nilai (value chain) menjadi penting untuk menjalin keterkaitan antar elemen/komponen model bisnis. Oleh karena itu Carpenter dan Sanders menegaskan tentang meraih dan melestarikan keunggulan-kompetitif dengan menggunakan rantai-nilai sebagai berikut: "Melakukan kegiatan yang sama lebih baik dari pada saingan biasanya menghasilkan keuntungan sementara. Sebagai alternatif, mengkonfigurasikan aktivitas rantai nilai dengan cara yang berbeda daripada pesaing membuat pesaing lebih sulit meniru kegiatan tersebut. Hal ini disebabkan oleh apa yang dikenal sebagai perlindungan perdagangan (trade off protection).

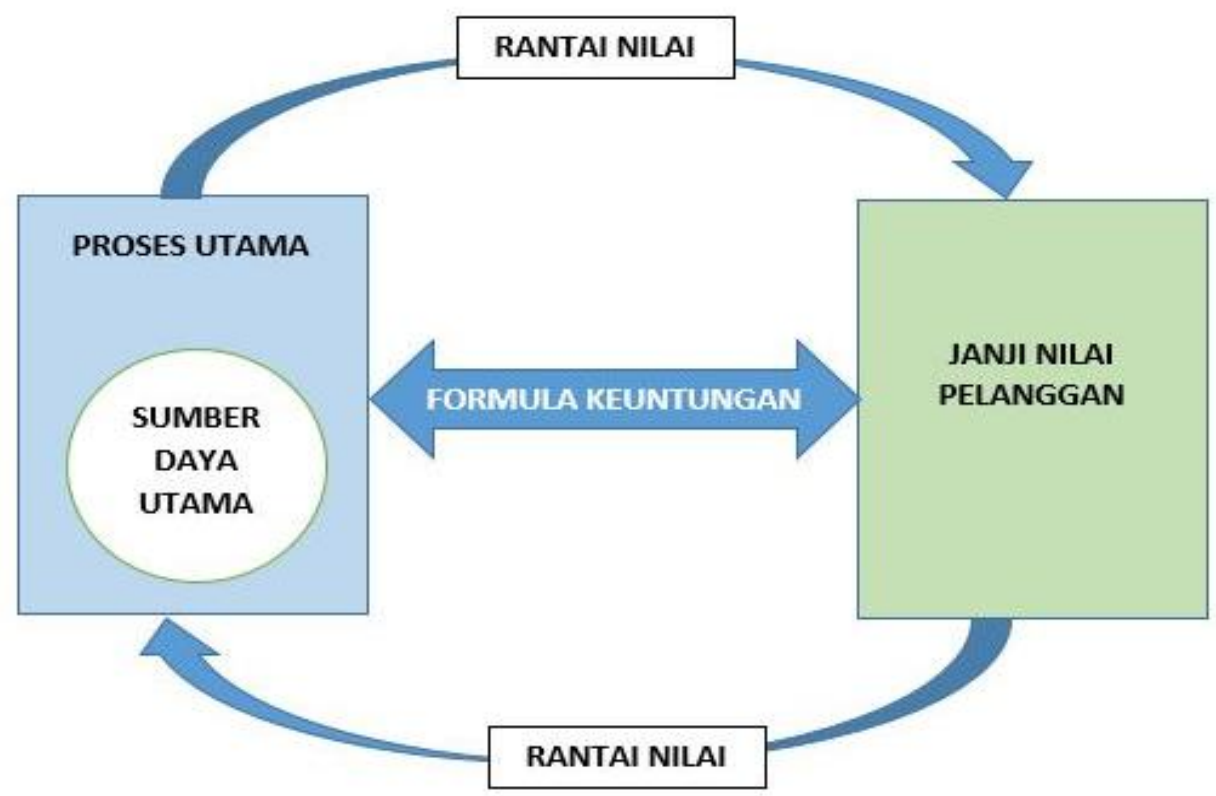

Sumber: Model Penelitian

Gambar 5. Deskripsi Model Bisnis

\section{Proposisi}

1. Proposisi 1: Transformasi model bisnis yang efektif menghasilkan kelestarian keunggulan kompetitif.

2. Proposisi 2: Transformasi model bisnis yang efektif menghasilkan nilai pelanggan yang tinggi.

3. Proposisi 3: Semakin tinggi nilai pelanggan yang dihasilkan dari transformasi model bisnis, semakin tinggi nilai tambah.

4. Proposisi 4: Semakin tinggi nilai tambah, semakin lestari keunggulan kompetitif.

Berdasarkan proposisi-proposisi tersebut, maka dibentuklah teori mini sebagai berikut:

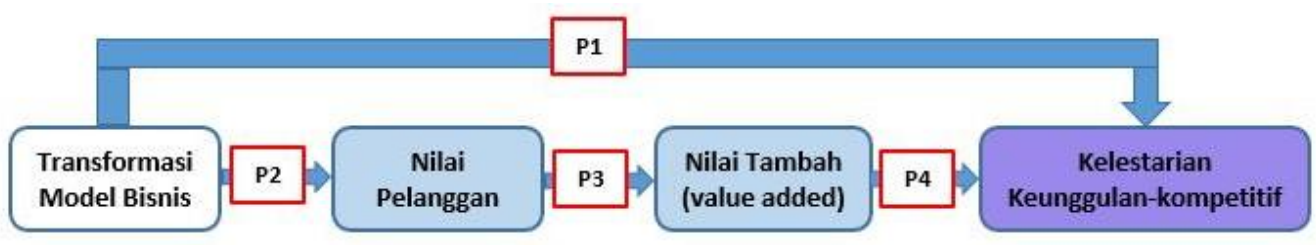

Sumber: Model Penelitian

Gambar 6. Teori Mini 


\section{SIMPULAN DAN SARAN}

Simpulan dari penelitian ini adalah bahwa transformasi model bisnis Go-jek memberikan nilai yang tinggi bagi pelanggan, di mana pelanggan merasakan manfaat dari aktivitas-aktivitas Go-jek. Peningkatan nilai pelanggan Go-jek ini meningkatkan nilai tambah Go-jek. Hal ini yang pada akhirnya melestarikan keunggulan-kompetitif Go-jek. Selain itu, serendipity effect keberadaan Go-jek adalah berdampak dan mengubah kehidupan pelanggan Go-jek menjadi lebih mandiri.

\section{Saran Praktis}

Selain itu, dari penelitian ini juga menghasilkan saran praktis yang dapat dilakukan Go-jek seperti:

1. Selain Transportasi, yang menjadi layanan utama Go-jek, Go-Food menjadi layanan yang banyak digunakan pelanggan. Manajemen perlu melakukan beberapa perbaikan dalam aplikasi Go-Food untuk lebih memuaskan pelanggan misal menyediakan thermal bag, sehingga makanan yang dipesan dapat sampai ke pelanggan dengan kondisi masih hangat.

2. Masih ada beberapa layanan yang dapat ditambahkan pada Go-jek berdasarkan ide dari kebutuhan masing-masing informan, seperti:

- Go-Member, layanan antarjemput langganan (mingguan/ bulanan)

- Go-Book, layanan beli buku

- Go-Pet, layanan hewan peliharaan

- Share-link lokasi pelanggan, yang dapat meningkatkan kepastian dan rasa aman karena posisi pelanggan dapat diketahui.

3. Hal-hal yang masih perlu dikembangkan/diperbaiki oleh Go-jek, yaitu

- Aplikasi
- Pengemudi

- Distribusi tutup hidung dan tutup kepala

\section{Keterbatasan Penelitian}

Penelitian ini memiliki keterbatasan yang hendaknya dapat menjadi perhatian pada penelitian selanjutnya, yaitu:

1. Peneliti tidak memiliki akses untuk melakukan penelitian langsung dengan pihak manajemen Go-jek sebagai informan kunci.

2. Peneliti tidak dapat memiliki akses terhadap laporan keuangan Go-jek, Grab, mau pun Uber. Hal ini juga menjadi suatu kendala untuk mengukur kinerja perusahaan secara keseluruhan maupun terhadap pesaing.

3. Informan yang ada terdiri dari latar belakang usia dan pendidikan yang berbeda-beda, sehingga dalam memberikan jawaban sangat tergantung pemahaman informan masingmasing, pewawancara perlu memberikan gambaran yang lebih jelas terhadap pertanyaaan yang diberikan.

4. Penelitian ini akan lebih komprehensif apabila ditelaah dari beberapa sudut pandang, seperti: manajemen Go-jek, pengemudi, pelanggan, mitra Gojek lainnya.

5. Penelitian model bisnis merupakan penelitian terhadap hal yang bersifat strategis, penelitian ini akan sangat menarik apabila dapat dilakukan dalam bentuk Forum Group Disccussion dari informan yang memiliki kemampuan strategis, seperti pakar akademisi, para pucuk pimpinan perusahaan. Di mana dalam hal ini tidak dapat dilakukan pada penelitian ini. 


\section{Agenda Penelitian Mendatang}

Go-jek sebagai obyek penelitian adalah merupakan fenomena yang sangat menarik, selain itu perkembangannya pun pesat sehingga hasil penelitian saat ini bisa saja akan berbeda dengan hasil penelitian 1 tahun mendatang. Selain itu proposisi yang dihasilkan pada penelitian ini pun akan menarik bila diteliti secara kualitatif dengan metode Focus Group Discussion dengan informan yang memiliki kualifikasi kemampuan strategis bisnis mau pun secara kuantitatif dengan sumber data pelanggan yang lebih banyak.

\section{DAFTAR PUSTAKA}

Afuah, Allan. 2004. Business Model: A Strategic Management Approach. Mc. Graw Hill.

Annisawati, Rakhmi. 2015. Sharing Economy: Konsep Bisnis Berbagi Sebagai Jawaban Dari Kebutuhan Konsumen, MarkPlus Institute.

Assen, Marcel Van, Van den Berg, Gerben dan Pietersma, Paul. 2008. Key Management Models: The 60+ models every manager needs to know, $\quad 2^{\text {nd }}$ Edition, Pearson Education.

Bogdan, Robert C. dan Steven J. Taylor. 1992. Introduction to Qualitative Research Methods: A Phenomenological Approach in the Social Sciences, alih bahasa Arief Furchan, Usaha Nasional, Surabaya.

Bernard E Silaban. 2006. Analisis Strategi PT. XYZ dengan Model Michael Porter, Esensi, Vol. No. 1.

Botsman, Rachel dan Rogers, Roo. 2010. What's Mine Is Yours: The Rise of Collaborative Consumption, Harper Business.
Boyce, C. dan Neale, P. 2006. Conducting In-Depth Interview: A Guide for Designing and Conducting In-Depth Interviews for Evaluation Input, Pathfinder International.

Carpenter, Mason A. dan Wm. Gerard Sanders. 2009. Strategic Management: A Dynamic Perspective, Pearson International Edition.

Chesbrough, Hendry, dan Rosenbloom, Richard. 2002. The Role of the Business Model in Capturing Value from Innovation: Evidence from Xerox Corporation's Technology spin-off companies, Harvard Business School.

Creswell, John W. 2009. Research Design: Qualitative, Quantitative and Mixed Methods Approaches, Sage Publications, Inc.

Gassmann, Oliver, Karolin, Frankenberger dan Csik, Michaela. 2016. Business Model Navigator: 55 Model Bisnis yang akan Mengubah Bisnis Anda, Elek Media Komputindo.

Hamari, Juho, Sjöklint, Mimmi, dan Ukkonen, Antti. 2015. The sharing economy: Why people participate in collaborative consumption. Journal of the Association for Information Science and Technology, 1-13.

Ihalauw, John J. O. I. 2008. Konstruksi Teori: Komponen dan Proses, PT Grasindo, Jakarta.

2016. Dari Realitas Bisnis ke Teori Mini: Penuntun Langkah Demi Langkah, Tisara Grafika.

Johnson, Mark W., Christensen, Clayton M., dan Kagermann, Henning. 2008. Reinventing Your Business Model. Harvard Business Review. 
Koopman, Christopher, Matthew Mitchell, and Adam Thierer. 2015. The Sharing Economy and Consumer Protection Regulation: The Case for Policy Change. Journal of Business, Entrepreneurship and the Law, Vol. 8, Issue 2, 529-545.

\section{5, The Sharing}

Economy: Issues Facing Platforms, Participants, and Regulators, Sharing Economy Workshop, Project No. P15-1200.

Kotler, Philip. 2001. Manajemen Pemasaran: Analisis, Perencanaan, Implementasi, dan. Kontrol, PT. Prehallindo, Jakarta.

Kotler, Philip dan Keller, Kevin Lane. 2009. Manajemen Pemasaran.Erlangga, Jakarta.

Moleong, Lexy J. 2010. Metodologi Penelitian Kualitatif. PT Remaja Rosdakarya Offset, Bandung.

Nursalam. 2011. Manajemen Keperawatan: Aplikasi dalam Praktik Keperawatan Profesional. Salemba Medika; Edisi 3.

Osterwalder, A., dan Pigneur, Y. 2010. Business Model Generation. Elex Media Komputindo.

Permana, Dian Jingga. 2013. Analisis Peluang Bisnis Media Cetak melalui Pendekatan Bisnis Model Canvas untuk Menentukan Strategi Bisnis Baru, Faktor Exacta.

Porter, Michael. 1985. Competitive Advantage: Creating and Sustaining Superior Performance.

Purhantara, Wahyu. 2009. Organizational Development based Change Management.
Purnamasari, Irma. 2008. Studi Partisipasi Masyarakat dalam Perencanaan Pembangunan di Kecamatan Cibadak Kabupaten Sukabumi.Thesis at Universitas Diponegoro, Semarang.

Sekaran, Uma dan Bougie, Roger. 2013. Research Methods for Business. John Wiley \& Sons Ltd.

Suriasumantri. Jujun S. 2001. Filsafat Ilmu: Sebuah Pengantar Populer, Pustaka Sinar Harapan, Jakarta.

Utama, Wandra. 2009. Pengaruh Adaptabilitas Lingkungan dan Orientasi Kewirausahaan terhadap Kualitas Aliansi untuk Meningkatkan Keunggulan Bersaing (Studi Kasus PT. Pos Indonesia Wilayah Jawa Barat).Thesis at Universitas Diponegoro Semarang.

https://en.wikipedia.org/wiki/Grab_(applicat ion) (diakses 28 November 2016)

https://id.wikipedia.org/wiki/Uber_(perusaha an) (diakses 28 November 2016)

http://koran.bisnis.com/read/20160913/250/5 83422/perang-demi-pangsa-pasar (diakses 15 September 2016)

http://presidenri.go.id/kabarpresiden/kegiatankepresidenan/presiden-revolusidigital-merevolusi-ekonomiindonesia.html (diakses 24 Oktober 2016)

http://print.kompas.com/baca/opini/dudukperkara/2016/04/06/EkonomiBerbagi-dan-Ketenagakerjaan (diakses 27 November 2016)

http://swa.co.id/swa/profile/michaelangelomoran-sosok-di-balik-nama-go-jek (diakses 24 Oktober 2016) 
http://teknologi.news.viva.co.id/news/read/6 84212-ditanya-persaingan-gojekagak-sulit-mengejar-kami (diakses 24 Oktober 2016)

http://teknologi.news.viva.co.id/news/read/7 80563-indonesia-sudah-masuk-eraekonomi-berbagi (diakses 27 November 2016)

http://www.collaborativeconsumption.com/ (diakses 18 September 2016)

http://www.cnnindonesia.com/teknologi/201 50707192338-185-65040/tak-cumaberkantor-uber-akan-bikin-pt-diindonesia/ (diakses 28 November 2016)

http://www.cnnindonesia.com/teknologi/201 50827064447-185-74785/bila-tarifpromo-dicabut-gojek-yakin-masihlaku/ (diakses 18 September 2016) http://www.cnnindonesia.com/teknologi/201 60805163842-185149479/membandingkan-kucurandana-investasi-gojek-dan-grab/ (diakases 24 Oktober 2016)

http://www.cosmogirl.co.id/artikel/read/869 8/Pilih-Gojek-Grab-Atau-Uber-IniKelebihan-dan-Kekurangannya (diakses26 Oktober 2016)

https://www.go-jek.com/ (diakses 5 Mei 2017)

http://www.republika.co.id/berita/koran/hala man-1/16/03/16/o44e4715-nadiemmakarim-pendiri-dan-ceo-gojekindonesia-membangkitkan-gairahusaha-tukang-ojek (diakses 24 Oktober 2016)

https://www.techinasia.com/how-go-jekbecame-unicorn (diakses 15 Oktober 2016) 